\title{
Analisis Pemecahan Masalah Biologi Berdasarkan Kemampuan Berpikir Kritis Peserta Didik SMA Kelas XI IPA
}

\author{
Paulina Rendra Endang ${ }^{1}$, Tantry AgnhityaSari ${ }^{2}$, Rina Hidayati Pratiwi ${ }^{3 *}$ \\ ${ }^{1}$ Mahasiswa Program Studi Pendidikan Biologi, FMIPA, Universitas Indraprasta PGRI \\ ${ }^{2}$ Program Studi Pendidikan Biologi, FMIPA, Universitas Indraprasta PGRI \\ ${ }^{3}$ Program Studi Pendidikan MIPA, Fakultas Pasca Sarjana, Universitas Indraprasta PGRI \\ *email: rina.hp2012@gmail.com
}

\begin{abstract}
Article History
Received:

17/06/2021

Revised:

13/07/2021

Accepted:

26/07/2021

Kata kunci:

Berpikir kritis

Biologi

Pemecahan

masalah

SMA

Key word:

Biology

Critical thinking

Problem solving

Senior high

school

ABSTRAK

Penelitian bertujuan untuk menganalisis kemampuan peserta didik dalam menyelesaikan soal pemecahan masalah Biologi berdasarkan kemampuan berpikir kritis mereka, membuat rencana, melaksanakan rencana dan memeriksa kembali jawaban. Metode penelitian yang digunakan adalah kualitatif deskriptif, dengan subjek penelitian sebanyak 26 peserta didik SMA PGRI 4 Jakarta. Hasil analisis data menunjukkan bahwa peserta didik yang berkemampuan berpikir kritis tinggi, sedang dan rendah memiliki hasil yang berbeda-beda. Pemecahan masalah Biologi SMA PGRI 4 Jakarta dikategorikan tinggi dengan hasil indikator memecahkan masalah 70\%, merencanakan strategi 58\%, melaksanakan strategi $48 \%$ dan memeriksa kembali kebenaran solusi 76\%. Disimpulkan bahwa tidak semua peserta didik yang memiliki kemampuan berpikir kritisnya tinggi juga memiliki tingkat pemecahan masalah yang tinggi, begitu juga sebaliknya tidak semua peserta didik yang memiliki kemampuan berpikir kritisnya rendah akan memiliki tingkat pemecahan masalah yang rendah.

ABSTRACT
The purposes of this research were to analyze the biological problem solving of class XI Science
based on critical thinking, plan making, plan application, and answer rechecking skills. The
method of this study is descriptive qualitative with 26 students of SMA PGRI 4 Jakarta as a subject
research. The results of data analysis revealed that through this research, we found that the study
result had some variations for the student. The category for biological problem solving of SMA
PGRI 4 student is high with the problem solving $70 \%$, strategy planning $58 \%$, strategy application
$48 \%$, and rechecking $76 \%$ by indicator. The conclusion of this research any student that have high
critical thinking ability not surely have high grade for problem solving. Any student that have low
critical thinking ability not surely have low grade for problem solving.
\end{abstract}

Copyright $\odot 2021$ LPPM Universitas Indraprasta PGRI. All Right Reserved

\section{PENDAHULUAN}

Pendidikan merupakan suatu usaha yang dilakukan manusia untuk menuju kehidupan yang lebih baik. Pernyataan ini sesuai dengan UndangUndang Republik Indonesia No. 20 Tahun 2003 tentang Sistem pendidikan Nasional (Pasal 1 Ayat 1) yang menyebutkan bahwa, pendidikan merupakan usaha sadar dan terencana untuk mewujudkan suasana belajar dan proses pembelajaran agar peserta didik secara aktif mengembangkan potensi dirinya untuk memiliki kekuatan spiritual keagamaan, pengendalian diri, kepribadian, kecerdasan, akhlak mulia serta keterampilan yang diperlukan dirinya, masyarakat, bangsa dan negara. Banyak faktor yang saling menunjang dalam proses pendidikan salah satunya adalah sekolah. Menurut Sarwono (2011), sekolah merupakan lingkungan pendidikan sekunder dimana sepertiga waktunya setiap hari dilewatkan di sekolah sehingga secara tidak langsung berpengaruh cukup besar terhadap perkembangan jiwa seorang remaja. Kegiatan yang dapat membantu perkembangan pendidikan adalah proses pembelajaran, dimana belajar yang baik bukan hanya sekedar mengingat, melainkan lebih luas dari itu yakni memahami arti yang diajarkan, mampu memecahkan masalah dan

Endang et al. Analisis Pemecahan Masalah Biologi EduBiologia Volume 1 Number 2 Juli 2021 
memiliki kemampuan berpikir yang luas bukan hanya sekedar penguasaan hasil latihan melainkan perubahan pola pikir (Indahsari et al., 2019). Pembentukan pola pikir yang lebih luas ditujukan untuk semua mata pelajaran, salah satunya adalah mata pelajaran Biologi.

Biologi menurut Wijayati (2007) adalah salah satu ilmu pengetahuan yang berhubungan dengan kehidupan organisme umumnya dan manusia khususnya. Biologi antara lain mengembangkan cara berpikir ilmiah melalui penelitian dan percobaan mengembangkan pengetahuan praktis dari metode Biologi untuk memecahkan masalah kehidupan individu dan sosial, merangsang studi lebih lanjut di bidang Biologi. Dalam pembelajaran Biologi banyak peserta didik yang mengalami kesulitan untuk menyelesaikan soalsoal Biologi terutama yang berkaitan dengan masalah kehidupan sehari-hari yang memerlukan pemahaman dan penalaran logis. Biologi berkaitan dengan cara mencari tahu dan memahami alam serta makhluk hidup secara sistematis sehingga pelajaran Biologi bukan hanya sebatas penguasaan materi tetapi juga pemahaman yang berguna untuk memecahkan suatu masalah (Agnafia, 2019).

Memecahkan suatu masalah dalam proses belajar mengajar sangatlah dibutuhkan oleh peserta didik, karena pada proses belajar mengajar peserta didik ditanamkan nilai-nilai keterampilan berupa keterampilan untuk menyelesaikan persoalan dengan baik dan benar sehingga keterampilan ini dapat digunakan dalam proses kehidupan terutama untuk menyelesaikan masalah yang terjadi pada proses kehidupan sehari-hari, untuk dapat dipecahkan prinsip utama dalam memecahkan suatu masalah adalah mendapatkan fakta dan bersikap terbuka akan ideide baru (Hardina \& Jamaan 2018; Nugraha \& Zanthy 2019). Pernyataan ini sejalan dengan pendapat Nasution (2005) yang menyebutkan bahwa memecahkan masalah dapat dipandang sebagai proses pelajar menemukan kombinasi aturan-aturan yang telah dipelajari lebih dahulu yang digunakan untuk memecahkan masalah tidak sekedar menerapkan aturan yang diketahui, akan tetapi juga menghasilkan pelajaran baru (Ulva 2016).

Pemecahan masalah merupakan suatu proses dimana peserta didik mampu menemukan kombinasi mengenai aturan-aturan yang telah dipelajari sebelumnya yang digunakan untuk memecahkan masalah yang baru (Siringoringo et al., 2018). Kemampuan pemecahan masalah terbukti sangat dibutuhkan dalam kehidupan bermasyarakat, orang yang memiliki kemampuan pemecahan masalah yang baik sangat dibutuhkan dalam berbagai profesi pekerjaan seperti guru, jika seorang guru tidak memiliki keterampilan pemecahan masalah dalam proses pembelajaran, dapat dipastikan guru tersebut tidak dapat menjawab dengan baik dan benar pertanyaan dari peserta didik, mengingat peserta didik pada jaman sekarang memiliki pola pemikiran yang tak terduga (Prastiwi \& Nurita, 2018).). Apalagi pada kondisi saat ini yang belum memungkinkan belajar di sekolah sehingga peserta didik terpaksa harus belajar menggunakan pembelajaran berbasis online. Oleh karena belajarnya menggunakan berbasis online maka peserta didik membutuhkan pemahaman dan kemampuan berpikir kritis yang tinggi.

Berpikir kritis merupakan kemampuan yang dimiliki seseorang untuk menganalisis suatu masalah dengan menggunakan data-data yang relevan, sehingga dapat ditemukan solusi dari permasalahan tersebut (Luzyawati, 2017). Menurut Wijaya (2010) berpikir kritis merupakan kegiatan menganalisis ide atau gagasan ke arah yang lebih spesifik, membedakannya secara tajam, memilih, mengidentifikasi, mengkaji dan mengembangkannya ke arah yang lebih sempurna (Santi et al., 2017). Selain dalam proses belajar mengajar kemampuan berpikir kritis juga sangat dibutuhkan dalam proses kehidupan bermasyarakat, orang yang memiliki kemampuan berpikir kritis yang baik ketika berada didalam forum seperti forum bermusyawarah, mereka dapat mengutarakan pendapat dengan penalaran yang logis apalagi pada saat masa pandemi sekarang ini semua peserta didik dianjurkan belajar dari rumah atau belajar secara online.

Jika dikaitkan dengan mewabahnya COVID19, maka dapat diketahui bahwa pembelajaran pada peserta didik di rumah tentunya tidak seefektif pembelajaran yang dilakukan di sekolah atau secara langsung. Pembelajaran dalam jaringan (daring) membuat peserta didik kurang fokus dan juga kurang memahami terhadap materi yang dipelajari saat itu. Kondisi demikian yang membuat peneliti tertarik untuk menganalisis peserta didik yang memiliki kemampuan berpikir kritis yang tinggi melalui penyebaran soal dalam bentuk soal essay dengan indikator kemampuan pemecahan masalah dan kemampuan berpikir kritis peserta didik.

Berdasarkan rumusan masalah yang telah dijelaskan, maka tujuan penelitian ini adalah untuk menganalisis kemampuan peserta didik dalam menyelesaikan soal pemecahan masalah 
biologi berdasarkan kemampuan berpikir kritis peserta didik pada materi sistem koordinasi (saraf).

\section{METODE PENELITIAN}

Penelitian ini dilakukan di SMA PGRI 4 Jakarta. Pelaksanaan penelitian dilakukan pada semester genap, selama lima bulan dimulai dari bulan Maret 2020 sampai Juli 2020.

Dalam menentukan subjek penelitian untuk memperoleh informasi diambil dari satu kelas yaitu kelas XI-IPA yang terdiri dari 26 siswa SMA PGRI 4 Jakarta tahun ajaran 2020/2021. Subjek dalam penelitian ini adalah peserta didik yang telah mempelajari materi sistem koordinasi pada kelas XI.

Jenis penelitian yang digunakan dalam penelitian ini adalah penelitian deskriptif dengan pendekatan kualitatif (Kurpius \& Stafford, 2006; Sugiyono, 2008). Dalam mengadakan suatu proyek penelitian deskriptif. Penulis tidak memanipulasi variabel-variabel atau menetapkan peristiwaperistiwa yang terjadi. Dengan demikian dalam penelitian ini akan menganalisis dan mendeskripsikan kemampuan berpikir kritis peserta didik dalam menyelesaikan masalah pada materi sistem saraf yang merupakan bagian dari sistem koordinasi.

Penelitian ini dilakukan dalam dua tahap, yaitu persiapan penelitian dan pengambilan data.

Pada tahap pengambilan data yang dilakukan yaitu menganalisis hasil tes uraian, yaitu dengan menggunakan tes soal essay kepada pesarta didik sehingga secara umum teknik pengumpulan data dalam penelitian ini adalah tes tertulis dan dokumentasi. Untuk tes tertulis dilakukan dua kali yaitu dengan mengggunakan essay untuk kemampuan berpikir kritis dan essay untuk pemecahan masalah Biologi. Bentuk tes dalam penelitian ini adalah bentuk essay atau uraian sebanyak 10 butir soal, serta penyebaran soal dengan sistem online yaitu dengan menggunakan google classroom. Pada pertemuan pertama peneliti melakukan penyebaran soal kemampuan berpikir kritis peserta didik, lalu hasil tes essay ini peneliti kategorikan peserta didik berdasarkan kriteria tinggi, cukup dan sedang. Selanjutnya dari kriteria tersebut pada pertemuan berikutnya peneliti menyebarkan soal kembali dengan indikator pemecahan masalah. Peneliti melakukan penskoran pada masing-masing jawaban peserta didik, jumlah indikator yang dinilai sebanyak 10 indikator. Pengolahan data ini memberikan skor pada hasil pemecahan masalah Biologi dan kemampuan berpikir kritis peserta didik. Untuk mengubah skor menjadi nilai memiliki ketentuan yaitu setiap indikator diberi skor sesuai dengan kriteria masing-masing indikator dengan jumlah skor maksimum 50.

Instrumen penelitian ini disusun sesuai dengan jenis data yang diperlukan untuk pengujian hipotesis. Jenis data tersebut adalah pemecahan masalah Biologi dan kemampuan berpikir kritis peserta didik, karena instrumen yang digunakan adalah soal essay semua sebanyak dua kali yaitu yang pertama untuk kemampuan berpikir kritis dan yang kedua untuk pemecahan masalah biologi.

Metode dokumentasi merupakan metode yang digunakan dengan mencari data melalui peninggalan tertulis seperti arsip dan termasuk juga buku-buku tentang pendapat teori dan lain-lain yang berhubungan dengan masalah penelitian. Dokumentasi ini digunakan untuk memperoleh informasi tentang nama-nama peserta didik yang digunakan dalam subjek penelitian.

Untuk menentukan nilai pemecahan masalah dan kemampuan berpikir kritis dapat dihitung dengan rumus:

$$
\text { Nilai }=\frac{\text { skor } \text { yang diperoleh }}{\text { skor maksimum }} \times 100 \%
$$

Proses analisis data pada dasarnya melalui tiga tahap analisis sesuai dengan model interactive Sugiono (2008), yaitu reduksi data, penyajian data, dan penarikan kesimpulan. Pada tahap menganalisis data inilah peneliti menggunakan triagulasi dari hasil jawaban peserta didik dan juga dari berbagai literatur yang ada.

Teknik yang digunakan untuk menjaga validitas data dalam penelitian ini digunakan teknik triangulasi. Triangulasi dalam penelitian ini adalah triangulasi metode. Triangulasi metode dilakukan dengan mengumpulkan data sejenis tetapi dengan menggunakan metode pengumpulan data yang berbeda, bahkan lebih jelas untuk diusahakan mengarah pada sumber data yang sama untuk menguji kemantapan informasinya.

Penelitian ini dikatakan berhasil apabila peserta didik dinyatakan mengalami peningkatan dalam pemecahan masalah berdasarkan kemampuan berpikir kritis pada materi sistem saraf dengan mencapai indikator-indikator keberhasilan. Memberikan pernyataan berupa soal essay, peneliti dapat mengetahui bagaimana kemampuan berpikir kritis dari peserta didik . 


\section{HASIL DAN PEMBAHASAN}

Berdasarkan penelitian yang telah dilakukan di SMA PGRI 4 Jakarta Tahun ajaran 2020/2021 dengan judul analisis pemecahan masalah Biologi berdasarkan kemampuan berpikir kritis peserta didik diperoleh data melalui hasil tes essay. Soal diberikan sebanyak dua kali, yaitu yang pertama tes kemampuan berpikir kritis peserta didik dengan indikator kemampuan berpikir kritis kategori tinggi, sedang, dan rendah. Selanjutnya, data kemampuan berpikir kritis dianalisis kemudian dengan memberikan soal pemecahan masalah Biologi. Salah satu keunggulan soal problem solving skills dalam bentuk uraian berkasus ialah dapat digunakan untuk mengukur problem solving skills siswa (Novitasari et al., 2015). Hasil data dari kemampuan berpikir kritis dan pemecahan masalah dianalisis dan digunakan sebagai hasil dari penelitian ini. Subjek pada penelitian ini adalah peserta didik kelas XI yang berjumlah 26 orang dan materi yang digunakan yaitu materi sistem koordinasi (saraf).

\section{a. Hasil Tes Kemampuan Berpikir Kritis}

Data yang diperoleh dari hasil tes kemampuan berpikir kritis peserta didik dalam bentuk essay dengan indikator kemampuan berpikir kritis kategori tinggi, sedang, dan rendah. Ada tiga kategori kemampuan berpikir kritis yang berbedabeda pada setiap peserta didik. Kemampuan berpikir kritis dengan kategori tinggi berjumlah 1 orang, kemudian kategori sedang berjumlah 22 orang dan kategori rendah berjumlah 3 orang. Pengelompokkan peserta didik berdasarkan kategori kemampuan berpikir kritis, selanjutnya peneliti mengklasifikasikan data tersebut berdasarkan indikator kemampuan berpikir kritis. Untuk indikator kemampuan berpikir kritis yang digunakan adalah indikator menurut Ennis (Fatmawati et al., 2014). Adapun data tersebut dapat dilihat pada Tabel 1 .

Tabel 1. Persentase kemampuan berpikir kritis peserta didik dari hasil tes berdasarkan persentase rata-rata

\begin{tabular}{l|c}
\hline $\begin{array}{c}\text { Indikator Kemampuan } \\
\text { Berpikir Kritis }\end{array}$ & $\begin{array}{c}\text { Kemampuan } \\
\text { Berpikir Kritis (\%) }\end{array}$ \\
\hline Menganalisis & 60 \\
Mensintesis & 64 \\
Memecahkan Masalah & 67 \\
Menyimpulkan & 37 \\
Mengevaluasi & 72 \\
Rata-rata & 60 \\
\hline
\end{tabular}

Berdasarkan hasil analisis kemampuan berpikir kritis peserta didik dapat diketahui bahwa indikator yang paling banyak tercapai adalah indikator mengevaluasi yaitu $72 \%$ sedangkan indikator yang paling sedikit tercapai adalah indikator menyimpulkan yaitu $37 \%$.

\section{b. Hasil Tes Pemecahan Masalah Biologi}

Data yang diperoleh dari hasil tes pemecahan masalah Biologi dalam bentuk essay juga dengan indikator pemecahan masalah dengan kategori tinggi, sedang, dan rendah. Ada tiga kategori pemecahan masalah Biologi yang berbeda-beda pada setiap peserta didik. Pemecahan masalah dengan kategori tinggi berjumlah 1 orang, kemudian kategori sedang berjumlah 18 orang dan kategori rendah berjumlah 7 orang. Pengelompokkan peserta didik berdasarkan kategori pemecahan masalah Biologi tersebut, selanjutnya peneliti mengklasifikasikan data tersebut berdasarkan indikator pemecahan masalah Biologi. Untuk indikator kemampuan pemecahan masalah Biologi yang digunakan adalah indikator menurut Polya (Winarti, 2017). Adapun data tersebut dapat dilihat pada Tabel 2.

Tabel 2. Persentase pemecahan masalah peserta didik dari hasil tes

\begin{tabular}{l|c}
\hline $\begin{array}{c}\text { Indikator Pemecahan } \\
\text { Masalah }\end{array}$ & $\begin{array}{c}\text { Persentase Pemecahan } \\
\text { Masalah (\%) }\end{array}$ \\
\hline Memahami Masalah & $70 \%$ \\
Merencanakan Strategi & $58 \%$ \\
Melaksanakan Strategi & $48 \%$ \\
Memeriksa kembali & $76 \%$ \\
kebenaran solusi & $63 \%$ \\
Rata-rata & \\
\hline
\end{tabular}

Berdasarkan hasil analisis Pemecahan Masalah Biologi peserta didik dapat diketahui bahwa indikator yang paling banyak tercapai adalah indikator memeriksa kembali kebenaran solusi yaitu $76 \%$, sedangkan indikator yang paling sedikit tercapai adalah indikator melaksanakan strategi yaitu $48 \%$.

\section{c. Kategori Pemecahan Masalah Biologi Berdasarkan Kemampuan Berpikir Kritis Peserta Didik.}

Adapun hasil analisis pemecahan masalah Biologi berdasarkan kemampuan berpikir kritis peserta didik (Winarti 2017) dapat dilihat pada Tabel 3. 
Tabel 3. Data pemecahan masalah biologi berdasarkan kemampuan berpikir kritis peserta didik

\begin{tabular}{|c|c|c|c|c|}
\hline No. Resp & $\mathbf{A}^{*}$ & $\mathbf{B} * *$ & C**** & D***** \\
\hline 13 & 39 & Tinggi & 31 & Sedang \\
\hline 22 & 37 & Sedang & 28 & Sedang \\
\hline 17 & 36 & Sedang & 34 & Sedang \\
\hline 25 & 36 & Sedang & 31 & Sedang \\
\hline 12 & 34 & Sedang & 33 & Sedang \\
\hline 24 & 34 & Sedang & 29 & Sedang \\
\hline 1 & 33 & Sedang & 38 & Tinggi \\
\hline 7 & 33 & Sedang & 26 & Rendah \\
\hline 10 & 33 & Sedang & 30 & Sedang \\
\hline 19 & 33 & Sedang & 26 & Rendah \\
\hline 23 & 33 & Sedang & 32 & Sedang \\
\hline 26 & 33 & Sedang & 35 & Sedang \\
\hline 8 & 32 & Sedang & 29 & Sedang \\
\hline 20 & 32 & Sedang & 25 & Rendah \\
\hline 20 & 32 & Sedang & 25 & Rendah \\
\hline 18 & 31 & Sedang & 28 & Sedang \\
\hline 4 & 30 & Sedang & 28 & Sedang \\
\hline 5 & 30 & Sedang & 26 & Rendah \\
\hline 6 & 30 & Sedang & 32 & Sedang \\
\hline 11 & 30 & Sedang & 29 & Sedang \\
\hline 15 & 30 & Sedang & 23 & Rendah \\
\hline 16 & 30 & Sedang & 24 & Rendah \\
\hline 21 & 30 & Sedang & 29 & Sedang \\
\hline 9 & 29 & Sedang & 29 & Sedang \\
\hline 3 & 26 & Rendah & 28 & Sedang \\
\hline 14 & 26 & Rendah & 26 & Rendah \\
\hline 2 & 24 & Rendah & 28 & Sedang \\
\hline
\end{tabular}

* Skor Kemampuan Berpikir Kritis

** Kategori Kemampuan Berpikir Kritis

*** Skor Pemecahan Masalah

***** Kategori Pemecahan Masalah

\section{Pemecahan masalah pada kelompok peserta didik berpikir kritis tinggi.}

Berdasarkan hasil uraian kemampuan berpikir kritis tinggi ke kemampuan pemecahan masalah sedang, peserta didik mampu memahami masalah terhadap soal yang diberikan dan peserta didik dapat menjelaskannya secara singkat sesuai dengan pemahamannya. Selain itu, peserta didik mampu merencanakan strategi serta mampu menjelaskan permasalahan yang sedang terjadi pada soal yang diberikan. Berdasarkan hasil uraian peserta didik juga mampu menunjukkan atau menjelaskannya secara detail mengenai permasalahan yang ada pada soal yang didapatkannya. Berdasarkan hasil uraian peserta didik juga mampu menjawab soal yang diberikan serta mampu memberikan alasan terhadap soal tersebut dengan pendapatnya sendiri.

\section{Pemecahan masalah pada kelompok peserta didik berpikir kritis sedang.}

a. Kemampuan berpikir kritis sedang ke kemampuan pemecahan masalah tinggi

Berdasarkan hasil uraian peserta didik mampu menjelaskan jawaban tersebut namun kurang teliti dalam memahami soal, sehingga jawaban yang dihasilkan tidak sesuai dengan soal yang diberikan. Selain itu, berdasarkan hasil uraian peserta didik mampu menjawab soal yang diberikan dengan secara rinci, maka peneliti mengalisis bahwa peserta didik tersebut mampu memahami materi tersebut dengan menggunakan pemikiran yang kritisnya. Berdasarkan hasil uraian, dalam melaksanakan strategi peserta didik mampu menjawab soal yang diberikan secara tepat, sehingga peneliti menganalisis bahwa tingkat kemampuan berpikir kritisnya dalam menyelesaikan soal tergolong tinggi. Berdasarkan hasil uraian peserta didik mampu juga menjawab soal yang diberikan dengan pemikirannya sendiri, sehingga peneliti menganalisis bahwa tingkat kemampuan berpikir kritisnya dalam menyelesaikan soal tergolong tinggi.

\section{b. Kemampuan berpikir kritis sedang ke} kemampuan pemecahan masalah sedang

Berdasarkan hasil uraian peserta didik mampu menjawab serta memahami soal yang diberikan. Hal ini dapat dilihat bahwa peserta didik tersebut mampu mengidentifikasi masalah, maka peneliti menganalisis bahwa peserta didik tersebut mampu memahami terhadap materi yang diberikan. Selain itu berdasarkan hasil uraian peserta didik mampu menjawab soal yang diberikan dengan secara rinci dan tepat, maka peneliti menganalisis bahwa peserta didik tersebut mampu memahami materi dengan baik sesuai pemikiran yang kritisnya. Berdasarkan hasil uraian, dalam melaksanakan strategi peserta didik mampu menjawab soal yang diberikan dengan sesuai akan tetapi belum tepat, sehingga peneliti menganalisis bahwa tingkat kemampuan berpikir kritisnya dalam menyelesaikan soal tergolong sedang. Berdasarkan hasil uraian peserta didik juga mampu menjawab soal yang diberikan dengan pemikirannya sendiri dengan singkat, sehingga peneliti menganalisis bahwa tingkat kemampuan berpikir kritisnya dalam menyelesaikan soal tergolong sedang karena kurang memahami materi yang diberikan. 
c. Kemampuan berpikir kritis sedang ke kemampuan pemecahan masalah rendah

Berdasarkan hasil uraian peserta didik mampu menjawab soal yang diberikan namun singkat, maka peneliti mengalisis bahwa peserta didik tersebut kurang memahami materi tersebut. Selain itu, berdasarkan hasil uraian peserta didik mampu menjawab soal namun kurang memahami apa yang ditanyakan sehingga peserta didik tersebut hanya mampu menyebutkan saja, maka peneliti menganalisis bahwa kemampuan berpikir kritisnya kurang dalam menyelesaikan soal yang ada. Berdasarkan hasil uraian, dalam melaksanakan strategi peserta didik mampu menjawab soal yang diberikan akan tetapi belum tepat, sehingga peneliti menganalisis bahwa tingkat kemampuan berpikir kritisnya dalam menyelesaikan soal tergolong rendah.Berdasarkan hasil uraian peserta didik juga mampu menjawab soal yang diberikan namun tidak ada solusi untuk masalah tersebut, sehingga peneliti menganalisis bahwa tingkat kemampuan berpikir kritisnya dalam menyelesaikan soal tergolong rendah.

\section{Pemecahan masalah pada kelompok peserta didik berpikir kritis rendah.}

\section{a. Kemampuan berpikir kritis rendah ke kemampuan pemecahan masalah sedang}

Berdasarkan hasil uraian peserta didik mampu menjawab serta mengidentifikasi soal yang diberikan namun belum bisa mengidentifikasi soal tersebut, sehingga peneliti menganalisis bahwa tingkat kemampuan berpikir kritisnya dalam menyelesaikan soal tergolong sedang. Dalam merencanakan strategi, peserta didik mampu menjawab soal yang diberikan dengan baik namun belum mampu mengidentifikasi soal dengan baik, sehingga peneliti menganalisis bahwa tingkat kemampuan berpikir kritisnya dalam menyelesaikan soal tergolong sedang. Sedangkan dalam melaksanakan strategi, peserta didik mampu menjawab soal dengan baik dalam menjelaskan dan mengidentifikan soal yang diberikan, sehingga peneliti menganalisis bahwa tingkat kemampuan berpikir kritisnya menyelesaikan soal tergolong sedang. Berdasarkan hasil uraian peserta didik untuk memeriksa kembali kebenaran solusi, mereka hanya mampu menjawab soal yang diberikan namun kurang mampu dalam menjelaskan dan mengidentifikasikan soal yang diberikan, sehingga peneliti menganalisis bahwa tingkat kemampuan berpikir kritisnya dalam menyelesaikan soal tergolong sedang.

\section{b. Kemampuan berpikir kritis rendah ke kemampuan pemecahan masalah rendah}

Berdasarkan hasil uraian peserta didik mampu menjawab soal yang diberikan namun belum bisa menjelaskan secara rinci dan saksama, sehingga peneliti menganalisis bahwa tingkat kemampuan berpikir kritisnya dalam menyelesaikan soal tergolong rendah.

Dalam merencanakan strategi, peserta didik hanya mampu menjawab soal yang diberikan namun kurang mampu dalam menjelaskan dan mengidentifikan soal yang diberikan, sehingga peneliti menganalisis bahwa tingkat kemampuan berpikir kritisnya menyelesaikan soal tergolong rendah. Sedangkan dalam melaksanakan strategi, peserta didik hanya mampu menjawab soal yang diberikan namun kurang mampu dalam menjelaskan dan mengidentifikan soal yang diberikan, sehingga peneliti menganalisis bahwa tingkat kemampuan berpikir kritisnya dalam menyelesaikan soal tergolong rendah.

Berdasarkan hasil uraian peserta didik untuk memeriksa kembali kebenaran solusi, mereka hanya mampu menjawab soal yang diberikan namun kurang mampu dalam menjelaskan dan mengidentifikasikan serta mencari solusi soal yang diberikan, sehingga peneliti menganalisis bahwa tingkat kemampuan berpikir kritisnya dalam menyelesaikan soal tergolong rendah.

Berdasarkan data hasil penelitian menunjukkan kemampuan berpikir kritis masing-masing peserta didik dalam pemecahan masalah biologinya berbeda-beda. Jika dilihat dari responden 13 bahwa pada saat menjawab soal dengan kemampuan berpikir kritis peserta didik tersebut termasuk dalam kategori berpikir kritis tinggi tapi saat menjawab soal pemecahan masalah biologi, peserta didik tersebut justru menurun dengan kategori sedang. Hal ini menunjukkan bahwa setiap peserta didik tidak selalu sama kemampuan berpikir kritisnya dengan pemecahan masalah biologi.

Peserta didik yang memiliki kemampuan berpikir kritis tinggi belum tentu pemecahan masalah biologinya juga tinggi karena ada peserta didik yang mampu memberikan ide atau gagasan secara kritis namun kurang mampu dalam memecahkan suatu masalah yang diberikan. Begitu juga sebaliknya, peserta didik yang memiliki berpikir kritis sedang dan rendah belum tentu pemecahan masalah biologinya juga rendah karena ada peserta didik yang mampu memcahkan suatu masalah namun kurang dalam memberikan ide atau gagasan yang kritis. 
Pentingnya untuk memiliki pemikiran dan pemahaman pada segala aspek kehidupan, baik dunia maupun akhirat terbukti benar adanya. Ketika kita memiliki pemikiran yang sehat, kita pasti memiliki pemahaman yang baik. Hasil di lapangan, tidak semua peserta didik dengan kemampuan berpikir kritis tinggi dan juga memiliki pemecahan masalah yang tinggi, begitu juga sebaliknya, peserta didik dengan kemampuan berpkir kritis rendah belum tentu memiliki pemecahan masalah yang rendah juga.

Kemampuan berpikir kritis peserta didik dipengaruhi oleh beberapa faktor. Faktor yang pertama adalah kondisi fisik, adalah kebutuhan fisiologi yang paling dasar bagi manusia untuk menjalani kehidupan. Kondisi fisik peserta didik tidak berkonsentrasi, berpikir secara tepat dan menanggapi respon jika kondisi fisiknya terganggu. Kondisi yang kurang mendukung mengubah keterampilan berpikir kearah negatif atau penurunan (Afcariono, 2008). Faktor kedua adalah motivasi, merupakan upaya untuk menimbulkan rangsangan, dorongan ataupun pembangkit tenaga seseorang agar mau berbuat sesuatu atau memperlihatkan perilaku tertentu yang telah direncanakan untuk mencapai tujuan yang ditetapkan. Peserta didik tidak dapat mengikuti proses pembelajaran di kelas dengan baik jika tidak ada motivasi belajar dalam dirinya, minat, perhatian, sikap, dan ketekunan. Faktor ketiga adalah kecemasan, timbul secara otomatis jika ada rangsangan berlebih dan tidak dapat diterima oleh peserta didik, kecemasan merupakan keadaan emosional seseorang terhadap suatu kemungkinan yang dapat membahayakan dirinya atau orang lain. Faktor keempat adalah perkembangan intelektual yaitu semakin bertambah umur anak, maka semakin tampak jelas kecenderungan dalam kematangan proses. Faktor kelima adalah interaksi yaitu antara pengajar dengan peserta didik, suasana akademik yang bebas dan aman dibutuhkan peserta didik agar pendapat dan keputusannya dapat ditunjukan selama kegiatan pembelajaran sehingga peserta didik dapat berkonsentrasi dalam memecahkan masalah yang diberikan (Kurniyasari et al., 2019).

Berpikir kritis itu bukan hanya sekedar tindakan sederhana dalam menerima informasi, akan tetapi berpikir kritis itu melibatkan proses berpikir secara aktif dan menganalisis apa yang akan diterima (Khasanah et al., 2017). Berdasarkan hasil penelitian, peserta didik yang memiliki kemampuan berpikir kritis tinggi juga memiliki tingkat pemecahan masalah yang tinggi, peserta didik yang memiliki kemampuan berpikir kritis sedang juga mereka memiliki tingkat pemecahan masalah yang sedang. Sebaliknya, peserta didik yang memiliki kemampuan berpikir kritis rendah, juga mereka memiliki tingkat pemecahan masalah yang rendah. Hal ini dipengaruhi oleh faktor pola pikir peserta didik dan metode serta model pembelajaran yang digunakan.

\section{KESIMPULAN}

Dari hasil penelitian dapat disimpulkan bahwa analisis pemecahan masalah Biologi berdasarkan kemampuan berpikir kritis peserta didik kelas XI IPA di SMA PGRI 4 Jakarta pada materi sistem saraf dikategorikan tinggi dengan hasil indikator memecahkan masalah, merencanakan strategi, melaksanakan strategi dan memeriksa kembali kebenaran solusi. Peserta didik yang memiliki kemampuan berpikir kritis tinggi mereka juga memiliki tingkat pemecahan masalah yang tinggi, peserta didik yang memiliki kemampuan berpikir kritis sedang mereka juga memiliki tingkat pemecahan masalah yang sedang. Demikian pula peserta didik yang memiliki kemampuan berpikir kritis rendah, mereka juga memiliki tingkat pemecahan masalah yang rendah. Hal ini dipengaruhi oleh faktor pola pikir peserta didik dan metode serta model pembelajaran yang digunakan.

\section{DAFTAR PUSTAKA}

Afcariono, M. (2008). Penerapan pembelajaran berbasis masalah untuk meningkatkan kemampuan berpikir siswa pada mata pelajaran biologi. Jurnal Pendidikan Inovatif, 3(2), 65-68.

Agnafia, D. N. (2019). Analisis kemampuan berpikir kritis siswa dalam pembelajaran Biologi. Florea Jurnal Biologi dan Pembelajarannya, 6(1), 45-53.

Fatmawati, H., Mardiyana., \& Triyanto. (2014). Analisis berpikir kritis siswa dalam pemecahan masalah matematika berdasarkan polya pada pokok bahasan persamaan kuadrat. Jurnal Elektronik Pembelajaran Matematika, 2(9), 899-910.

Hardina, S. P. \& Jamaan, E. Z. (2018). Analisis kemampuan pemecahan masalah matematis peserta didik berdasarkan taksonomi solo pada kelas VIII SMPN 1 Padang. Jurnal Edukasi dan Penelitian Matematika, 7(3), 101-107.

Indahsari, I. N., Situmorang, J. C. \& Amelia, R. (2019). Analisis kemampuan pemecahan masalah matematis dan self efficacy siswa 
MAN. Journal on Education, 01(02), 256264.

Khasanah, N., Tomi, L., \& Mugianto. (2017). Analisis berpikir ktitis siswa dalam pemecahan masalah matematika pada materi lingkaran. Prosiding Seminar Nasional Hasil Penelitian dan Abdimas, 2017, 291299.

Kurniyasari, H., Hidayat, S. \& Harfian, B. A. A. (2019). Analisis keterampilan berpikir kritis siswa SMA di Kecamatan Sako dan AlangAlang Lebar. BIOMA: Jurnal Biologi dan Pembelajaran Biologi, 4(1), 1-15.

Kurpius, S. E., \& Stafford, M. E. (2006). Testing and Measurement: A User Friendly Guide. Sage Publications, Inc.: California.

Luzyawati, L. (2017). Analisis kemampuan berpikir kritis siswa SMA materi alat indera melalui model pembelajaran Inquiry Pictorial Riddle. EduSains: Jurnal Pendidikan Sains \& Matematika, 5(2), 9-21.

Nasution. (2005). Berbagai Pendekatan dalam Proses Belajar dan Mengajar. Bumi Aksara: Bandung.

Novitasari, N., Ramli, M., \& Maridi. (2015). Mengukur problem solving skills siswa SMA pada mata pelajaran Biologi. Jurnal Biologi Edukasi, 1(7), 1-6.

Nugraha, A., \& Zanthy, L. S. (2019). Analisis kemampuan pemecahan masalah siswa SMA pada materi sistem persamaan linear. Journal on Education, 01(02), 179-187.
Prastiwi, M. D. \& Nurita, T. (2018). Kemampuan pemecahan masalah pada siswa kelas VII SMP. E-journal-pensa, 06(02), 98-103.

Sarwono, S. W. (2011). Psikologi Remaja. Raja Grafindo Persada: Jakarta.

Santi, N., Soendjoto, M. A., \& Winarti, A. (2017). Kemampuan berpikir kritis mahasiswa pendidikan Biologi melalui penyelesaian masalah lingkungan. BIOEDUKASI: Jurnal Pendidikan Biologi, 11(1), 35-39.

Siringoringo, E., Yaumi, M. R., Santhalia, P. W. \& Kusairi, S. (2018). Kemampuan pemecahan masalah siswa kelas XI SMA pada materi suhu dan kalor. Jurnal Pendidikan Matematika dan Sains, 6(2), 114-122.

Sugiyono. (2008). Metode Penelitian Kuantitatif Kualitatif dan $R \& D$. Alfabeta: Bandung.

Ulva, S. (2016). Kemampuan pemecahan masalah matematis siswa ditinjau melalui model SAVI dan konvensional. Jurnal Pendidikan Matematika, 2(2).

Wijayati. (2007). Biologi Kelas X. Ganeca: Bandung.

Winarti, D., Jamiah Y., \& Suratman, D. (2017). Kemampuan pemecahan masalah siswa dalam menyelesaikan soal cerita berdasarkan gaya belajar pada materi pecahan di SMP. Jurnal Pendidikan dan Pembelajaran Khatulistiwa, 6(6), 1-9. 